\title{
Treatment of Malignant Glaucoma
}

\author{
Cigdem Altan, ${ }^{1}$ Isıl Pasaoglu, ${ }^{1}$ Sukru Bayraktar ${ }^{2}$ \\ 1 University of Health Sciences Beyoglu Eye Training and Research Hospital, Istanbul, Turkey \\ 2Self-Employed Physician
}

\begin{abstract}
Malignant glaucoma is one of the most challenging conditions in ophthalmology. The exact etiology of this complication is not fully understood, and its management is usually challenging. This brief report discusses current treatment strategies for this relatively uncommon form of secondary glaucoma.

Keywords: Glaucoma, malignant glaucoma, treatment.
\end{abstract}

\section{Introduction}

Malignant glaucoma, or aqueous misdirection syndrome, is characterized by a uniform shallowing or flattening of both the central and peripheral anterior chambers in an eye with normal to elevated intraocular pressure despite patent iridotomies. It is most commonly encountered after filtration surgery and cataract extraction, in eyes with closed angles, and after laser iridotomy, capsulotomy, cyclophotocoagulation, suture lysis, photocoagulation, or following the onset of topical miotic therapy (I-8).

Although the exact mechanism of malignant glaucoma remains unclear, an alteration in the anatomical relationship of the lens, ciliary body, and anterior hyaloid face causing aqueous misdirection and blockade has been suggested in the pathogenesis. The aqueous is thought to be entrapped inside the vitreous cavity as aqueous pockets, resulting in forward movement of the iris-lens diaphragm, which causes the secondary angle closure glaucoma $(1,9)$.

The first line of treatment in malignant glaucoma is aqueous suppressants, such as beta-blockers, alpha adrenergic agonists, or topical and oral carbonic anhydrase inhibitors. Cycloplegics and hyperosmotic agents, including oral glycerol, isosorbide, or intravenous mannitol, are other important components of treatment. The goal is to decrease aqueous humor production, shrink the vitreous body, and move the iris-lens diaphragm backward. Approximately $50 \%$ of cases respond to medical therapy, but recurrence is common following cessation of cycloplegics (I, 9, 10).

Peripheral iridotomy should be performed initially to exclude the pupillary block mechanism, or if there is a question of the patency of a previous iridotomy (8).

Neodymium: yttriumaluminum-garnet (Nd: YAG) laser posterior capsulotomy and hyaloidotomy have been used in aphakic or pseudophakic eyes that are refractory to medical treatment with varying degrees of success. The mechanism was proposed to relieve the blockade and reverse the aqueous misdirection (2, I I-|4).

Direct argon laser application through a peripheral iridectomy has also been used in an attempt to shrink the ciliary processes and relieve the cilio-lenticular block of the anterior flow of aqueous $(15,16)$.

Transscleral diode laser photocoagulation, which reduces aqueous production and its flow, is another option in the treatment of malignant glaucoma (I7).

In cases that are refractory to medical and/or laser treatment, surgical treatment must be used. 
A pars plana vitrectomy (PPV) has been reported to treat pseudophakic malignant glaucoma in $67 \%$ to $100 \%$ of cases $(2, \mathrm{II})$. Vitrectomy was thought to prevent aqueous accumulation inside the vitreous cavity (2). However, this may not be enough to break the cycle of malignant glaucoma because the ciliolenticular aqueous blockade cannot be completely eliminated by removing the central vitreous only, and aqueous accumulation may continue despite the procedure (18). It requires vitreoretinal surgical expertise and cannot be performed easily and safely by an anterior segment surgeon.

In a retrospective series, the relapse rate was $100 \%$ after medical therapy, 75\% after YAG laser capsulotomy and a hyaloidotomy, $75 \%$ after a conventional vitrectomy, and $66 \%$ after a anterior vitrectomy in combination with an iridectomy-zonulectomy (19). It was postulated that all of the tissues (iris, lens capsule, anterior hyaloid, and anterior vitreous) had to be removed completely in order to create a permanent passage between the anterior chamber and the vitreous cavity, a task not easily accomplished by PPV alone (20).

We have already reported our surgical approach in 2 cases of pseudophakic malignant glaucoma, which consisted of peripheral iridectomy, zonulectomy, hyaloidectomy, and anterior vitrectomy successfully performed by an anterior segment surgeon using a vitreous cutter inserted through a clear corneal incision (9). This technique creates a permanent passage between the anterior chamber and the vitreous cavity by eliminating the aqueous misdirection and helps us to understand the pathogenesis of the disease better.

Because malignant glaucoma is a relatively rare disease, it is difficult to compose a large study group. Its management is usually challenging and varies according to the patient. The success of treatment will increase when the pathogenesis of the disease is better understood.

\section{Disclosures}

Peer-review: Externally peer-reviewed.

Conflict of Interest: None declared.

Authorship Contributions: Involved in design and conduct of the study (CA); preparation and review of the study (CA, IP); data collection (CA, IP, SB).

\section{References}

I. Shahid H, Salmon JF. Malignant glaucoma: a review of the modern literature. J Ophthalmol 20I2;20 I2:852659. [CrossRef]

2. Byrnes GA, Leen MM, Wong TP, Benson WE. Vitrectomy for ciliary block (malignant) glaucoma. Ophthalmology 1995; 102: I 308-II. [CrossRef]

3. Tomey KF, Senft SH, Antonios SR, Shammas IV, Shihab ZM, Traverso $C E$. Aqueous misdirection and flat chamber after posterior chamber implants with and without trabeculectomy. Arch Ophthalmol 1987; 105:770-3. [CrossRef]
4. Lynch MG, Brown RH, Michels RG, Pollack IP, Stark WJ. Surgical vitrectomy for pseudophakic malignant glaucoma. Am J Ophthalmol 1986; 102: I49-53. [CrossRef]

5. Cashwell LF, Martin TJ. Malignant glaucoma after laser iridotomy. Ophthalmology 1992;99:65I-8. [CrossRef]

6. Arya SK, Sonika, Kochhar S, Kumar S, Kang M, Sood S. Malignant glaucoma as a complication of $\mathrm{Nd}$ :YAG laser posterior capsulotomy. Ophthalmic Surg Lasers Imaging 2004;35:248-50.

7. Azuara-Blanco A, Dua HS. Malignant glaucoma after diode laser cyclophotocoagulation. Am J Ophthalmol 1999;127:467-9.

8. Foreman-Larkin J, Netland PA, Salim S. Clinical Management of Malignant Glaucoma. J Ophthalmol 20 I5;20 I 5:283707. [CrossRef]

9. Basgil Pasaoglu I, Altan C, Bayraktar S, Satana B, Basarır B. Surgical Management of Pseudophakic Malignant Glaucoma via Anterior Segment-Peripheral Iridectomy Capsulo-Hyaloidectomy and Anterior Vitrectomy. Case Rep Ophthalmol Med 20I2;201 2:794938. [CrossRef]

10. Simmons RJ, Thomas JV. Yaqub Malignant glaucoma. In: Ritch R, Shileds MB, Krupin T, editors. The Glaucomas. St Louis; Mosby: 1989. p. 1251-63.

I I. Little BC, Hitchings RA. Pseudophakic malignant glaucoma: Nd:YAG capsulotomy as a primary treatment. Eye (Lond) 1993;7:102-4. [CrossRef]

12. Epstein DL, Steinert RF, Puliafito CA. Neodymium-YAG laser therapy to the anterior hyaloid in aphakic malignant (ciliovitreal block) glaucoma. Am J Ophthalmol 1984;98: I37-43. [CrossRef]

13. Brown RH, Lynch MG, Tearse JE, Nunn RD. Neodymium-YAG vitreous surgery for phakic and pseudophakic malignant glaucoma. Arch Ophthalmol 1986;104:|464-6. [CrossRef]

14. Halkias A, Magauran DM, Joyce M. Ciliary block (malignant) glaucoma after cataract extraction with lens implant treated with YAG laser capsulotomy and anterior hyaloidotomy. $\mathrm{Br}$ J Ophthalmol 1992;76:569-70. [CrossRef]

15. Lee PF, Shihab Z, Eberle M. Partial ciliary process laser photocoagulation in the management of glaucoma. Lasers Surg Med 1980; 1:85-92. [CrossRef]

16. Herschler J. Laser shrinkage of the ciliary processes. A treatment for malignant (ciliary block) glaucoma. Ophthalmology 1980;87: I I55-9. [CrossRef]

17. Stumpf TH, Austin M, Bloom PA, McNaught A, Morgan JE. Transscleral cyclodiode laser photocoagulation in the treatment of aqueous misdirection syndrome. Ophthalmology 2008; I I 5:2058-6I. [CrossRef]

18. Sharma A, Sii F, Shah P, Kirkby GR. Vitrectomy-phacoemulsification-vitrectomy for the management of aqueous misdirection syndromes in phakic eyes. Ophthalmology 2006; I I 3: I 9068-73.

19. Debrouwere V, Stalmans P, Van Calster J, Spileers W, Zeyen T, Stalmans I. Outcomes of different management options for malignant glaucoma: a retrospective study. Graefes Arch Clin Exp Ophthalmol 2012;250:13I-4I. [CrossRef]

20. Bitrian E, Caprioli J. Pars plana anterior vitrectomy, hyaloido-zonulectomy, and iridectomy for aqueous humor misdirection. Am J Ophthalmol 2010;150:82-7. [CrossRef] 